\title{
Impact of urbanization on climate change and geographical analysis of physical land use land cover variation using RS-GIS
}

\author{
Jeykumar R.K.C.* and Chandran S. \\ Department of Civil Engineering, Thiagarajar College of Engineering, Thirupparankundram, Madurai-625009, Tamil Nadu, India \\ Received: 30/03/2018, Accepted: 19/01/2019, Available online: 22/01/2019 \\ *to whom all correspondence should be addressed: e-mail: rkcjey@gmail.com \\ https://doi.org/10.30955/gnj.002701
}

\begin{abstract}
This study focuses on the impact of climate change on rainfall-runoff pattern, and to assess the surface runoff and groundwater recharge potential from the intensified rainfall for the effective management of surface and groundwater resources in Tirunelveli city. The rainfall contribution is consistent, dependent, maximum and intensified during the month of November followed by October and December. The intensified rainfall in these months causes a temperature decrease and the climate becomes more and more colder than ever. The indices SPI and DI clear show that there is a change in climatic pattern. Landuse Landcover (LULC) analysis shows that the residential area and mining area is on the increasing trend, Village area is slightly increasing, agricultural area and dense scrub area is on the decreasing trend. The present capacity of the storage tanks available in Tirunelveli city is less than the maximum runoff generated during the month of November. The increase in residential area in LULC reflects the direct linear relation with the population increase of the city. The impact of urbanization leads to LULC change with the loss of agricultural land and water bodies.
\end{abstract}

Keywords: Water resource management; rainfall-runoff; land use land cover; urbanization and climate change; SPI and DI indices.

\section{Introduction}

Mankind or any form of life on this planet earth faces a challenge for their day to day biological process needs, that is water. Water-related problems are increasingly recognized as one of the most immediate and serious environmental threats to humankind. Water use has more than tripled globally since 1950 and one out of every six persons does not have regular access to safe drinking water. Lack of access to a safe water supply and sanitation, affects the health of 1.2 billion people annually (WHO and UNICEF, 2000). The latest Global Environment Outlook of the United Nations Environmental Programme (UNEP) reports that about one third of the world's population currently live in countries suffering from moderate-to-high water stress, where water consumption is more than $10 \%$ of renewable freshwater resources. These problems may be attributed to many factors. One such factors is inadequate water management which accelerates the depletion of surface water and groundwater resources. The effective management of urban water is based on a scientific understanding of the impact of human activity on the urban hydrological cycle and the environment itself. Such anthropogenic impacts, which vary broadly in time and space, need to be quantified with respect to local climate, urban development, cultural, environmental and religious practices, and other socio-economic factors (Jiri Marsalek et al., 2007).

According to Intergovernmental Panel on Climate Change Fourth Assessment Report the world indeed has become more drought prone with higher frequencies of extreme events (IPCC REPORT, 2007) some clear instances around the world is noticed, like changing trends of monsoonal rainfall over India due to climate change (Naidu et al., 2009) increase in drought events in UK (Arnell, 2007), in Korean peninsula (Kyoung et al., 2011), in Iran (Sayari et al., 2013), and over Indian subcontinent (Sivakumar and Stefanski, 2011) describing the impacts of climate change (Mundetia and Sharma, 2015). In India, it is found that the rise in annual mean surface temperature over India is in agreement with the reported rise of global surface temperature. Hingane et al. (1985), Srivastava et al. (1992), Rupakumar et al. (1994), De and Mukhopadhyay (1998), Pant et al. (1999), Singh et al. (2001), and Singh and Sontakke (2002) also reported increasing trend in surface temperature in different parts of India (Lairenjam, 2017).

Climate change increases the amount of runoff even in areas with high amount of rainfall and snow (Sarkar, 2015) and decreases infiltration thereby reducing the recharge of the aquifer. The climate prediction anticipates disturbed hydrological cycle and regional climatic variability in future. Impact of climate change poses a high threat to the water resources of the globe (Sarkar, 2015). Water quality has been degraded by domestic and industrial pollution sources as well as non-point sources. In some places, water is withdrawn from the water resources, which become polluted owing to a lack of 
sanitation infrastructure and services. Hence there is an immediate need for managing fresh water resources i.e. runoff rainfall, effectively for the present and future needs of the population.

The objectives are

a. To study the physical variation in geographical area by land use and land cover analysis using RSGIS in Tirunelveli LPA.

b. To plan for a effective management of fresh water resources in Tirunelveli city using rainfall and runoff analysis.

c. To find out the impact of urbanization on climate change using dry and wet indices of Tirunelveli city.

\section{Data and methodology}

\subsection{Data collection and synthesis}

The methodology adopted for the study is to collect secondary data such as the population census data, rainfall data, climatological data, groundwater level, and Landsat GIS images of the study area. The rainfall of the city is purchased from State Ground water resource data centre of Tamil Nadu. The secondary data is analysed for the basic hydrological characterization such as rainfall trend, runoff, groundwater recharge, population growth, and land use land cover pattern. The census is obtained from the website of the Tirunelveli corporation. This census data is analysed to find out the growth pattern and also to forecast future population of the city. The GIS image for the year 1973, 1992 and 2012 is obtained from the USGS website. These GIS images are processed in Arc-GIS to find out the extent of urbanization, changes in land use land cover pattern. Statistical rainfall analysis is also done for descriptive statistics, observed probability- predicted probability analysis(P-P), regression analysis, absolute correlation among the months, and also to draw P-P plot, Box plot, Area plot etc.

\subsection{Study area}

Tirunelveli city is the sixth largest city of Tamilnadu, and is located in the southern part of India. This city spreads over an area of $108.65 \mathrm{Sq} . \mathrm{Km}$ and having local planning area of 651 Sq.Km. Tirunelveli District is having a geographical area of 6,823 Sq.Km, located in the south eastern portion of Tamil Nadu. Population explosion and urbanisation is very aggressive and changes the land use pattern of the city. The Agriculture is the major source of income of this city. This city practices agriculture even in the heart of the city due to the river Tamiraparani which flow across the city. This river feeds Tirunelveli and Tuticorin district. Tirunelveli district is surrounded by Virudhunagar District on the North, Western Ghats on the West, Kanyakumari District on the South and Tuticorin District on the East. Tirunelveli District is located in geo referencing points between $08^{\circ} 08^{\prime}$ and $09^{\circ} 23^{\prime}$ of Northern latitude and $77^{\circ} 09^{\prime}$ and $77^{\circ} 54^{\prime}$ of Eastern longitude.

\subsection{Climate}

Tirunelveli district receives rainfall in all seasons and the normal annual rainfall for Tirunelveli city is $608 \mathrm{~mm}$. The monthly average relative humidity of the city varies from 29 to 54\%. The Hydro-meteorological feature of the study area divides the year into two major classifications as 1) Monsoon season spanning from June to December and 2) Non-monsoon season spanning from January to May. The maximum temperature is $39.4^{\circ} \mathrm{C}$ and occurs in the month of May. The minimum temperature is $21.7^{\circ} \mathrm{C}$, occurs in the month of January. The wind direction is predominantly towards North and West in the morning, and towards South and East in the evening. (Courtesy: State Groundwater Resources Division, Public Works Department, Tamil Nadu, India).

\section{Results and discussion}

The analysis is done for LULC to understand the trend of city growth, changes in land use area for the management of both the surface water and groundwater resources. Population analysis is done to estimate the present and future water demand. Rainfall-runoff analysis is done to understand the trend of rainfall runoff pattern for the effective management fresh water and ground water resources.

\subsection{Population growth analysis}

The census and forecast of the population of Tirunelveli city, and its peri urban area is shown in the Table 1 below. The population growth analysis is carried out with the census records from the year 1971 to 2011 by various methods, Geometrical increase method is found to be most suitable for this city as is inferred from the standard deviation and regression analysis. The forecast of the population for the year 2051 by Geometric increase method will be 9,05,101 persons. Table 1 shows that the migration from peri urban areas during the year 2001 is 30,420 persons and is nearly $26.86 \%$ of the peri urban area population.

\subsection{Land use land cover analysis}

The LULC(Land use land cover) analysis is done to apportion various land cover areas especially agricultural, forest, residential and water storage structures such as tanks for the management of water resources. LULC analysis is done during the year 1973 when the source of income is predominantly agriculture. LULC is done for the year 1992 when other industries started grooming and urbanisation is on the rise. LULC is done for the year 2012 when the urban agglomeration is dense and the city area expands. The LULC analysis for the year 1973 shows that the percentage of agricultural area is $54.8 \%$, dense scrub is $27.9 \%$, village area in the peri urban area is $2.19 \%$, the residential area is $3.91 \%$, the river area is $0.68 \%$, the area of tank is $8.43 \%$, mining area is $0.87 \%$, and the total area of reserved forest is $0.99 \%$. The digitized image of the landsat image obtained from the global land cover facility is shown in Figure 1. 
Table 1. Population data of Tirunelveli city and LPA

\begin{tabular}{|c|c|c|c|c|c|c|}
\hline \multirow{2}{*}{ Year } & \multicolumn{3}{|c|}{ Corporatıon Area } & \multicolumn{3}{|c|}{ Perı Urban Area } \\
\hline & Population & Increase/decrease(-) & $\%$ of Variation & Population & Increase/decrease(-) & $\%$ of Variation \\
\hline 1971 & 241013 & -- & -- & 82145 & -- & --- \\
\hline 1981 & 291104 & 50091 & 20.78 & 95038 & 12893 & 15.70 \\
\hline 1991 & 321454 & 30350 & 10.43 & 113250 & 18212 & 19.16 \\
\hline 2001 & 411831 & 90377 & 28.12 & 82830 & $(-) 30420$ & $(-) 26.86$ \\
\hline 2011 & 477838 & 66007 & 16.02 & -- & -- & -- \\
\hline 2021 & 562306 & 84468 & 17.68 & & & \\
\hline 2031 & 661706 & 99400 & 17.68 & & & \\
\hline 2041 & 778677 & 116971 & 17.68 & & & \\
\hline 2051 & 916325 & 137648 & 17.68 & & & \\
\hline
\end{tabular}

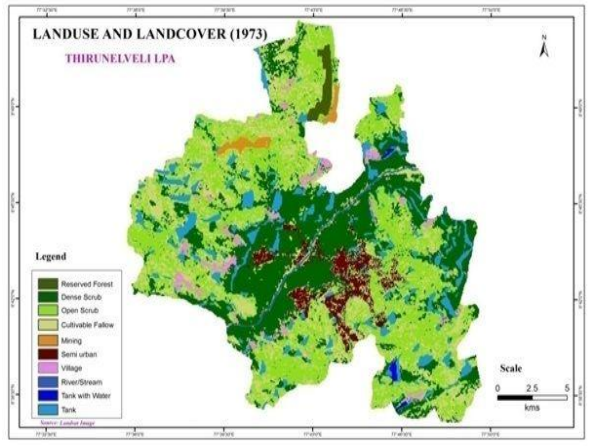

Figure 1. Landuse and Landcover of Tirunelveli LPA (1973)

\subsection{Land use and land cover for Tirunelveli local planning} area for the year 1992

The Land use land cover for the year 1992 shows that the percentage of agricultural area is $50.73 \%$, dense scrub is $27.5 \%$, village area in the peri urban area is $2.61 \%$, the residential area is $7.53 \%$, the river area is $0.68 \%$, the area of tank is $8.22 \%$, mining area is $1.69 \%$, and the total area of reserved forest is $0.99 \%$. The digitized image of the landsat image obtained from the global land cover facility is shown in Figure 2.

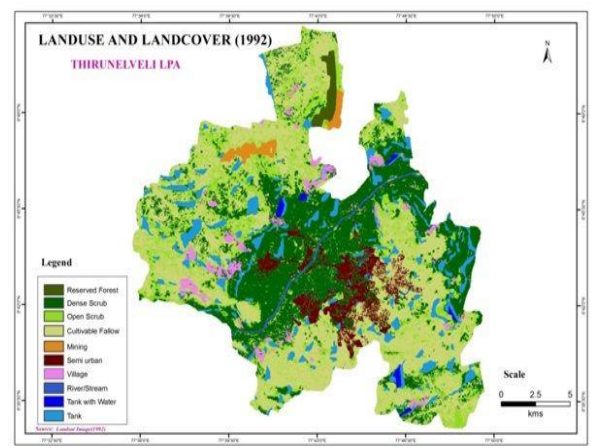

Figure 2. Landuse and Landcover of Tirunelveli LPA (1992)

3.4. Land use and land cover for Tirunelveli local planning area for the year 2012

The Land use land cover for the year 2012 shows that the percentage of agricultural area is $50.26 \%$, dense scrub is $25.14 \%$, village area in the peri urban area is $2.63 \%$, the residential area is $9.65 \%$, the river area is $0.68 \%$, the area of tank is $8.13 \%$, mining area is $2.48 \%$, and the total area of reserved forest is $0.99 \%$. The digitized image of the Landsat image obtained from the global land cover facility is shown in Figure 3.

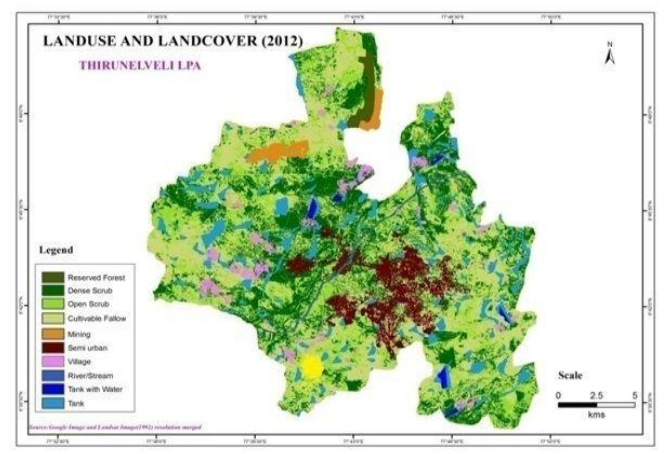

Figure 3. Landuse and Landcover of Tirunelveli LPA (2012)

The Land use Land cover images of Figures 1-3 for the year 1973, 1992, 2012 are showing a decline pattern of agricultural area from 1973 due to urbanisation. The Land use Land cover pattern of 2012 shows the agricultural area is reduced by $4.54 \%$ of the total land area and the decline is nearly $8.3 \%$ of the agricultural area since 1973 . Considering this rate of decline, the agricultural area in the year 2051 may be further reduced by $6 \%$. The area of dense scrub is also declining by $2.75 \%$ of total land area and $10 \%$ of the dense scrub area. The residential area is increased by $5.74 \%$ of total land area and increased to $146.8 \%$ since 1973 . Similarly the village area increases by $0.42 \%$ of total land area and increased to $19.17 \%$ since 1973. This shows that the urbanisation is taking place at a faster rate since 1973. Taking into account the rate of Land use Land cover changes from 1973 to 2012, the residential area may increase by $80 \%$ in the year 2051 from 2012 residential area cover.

The Land use Land cover pattern changes of residential area for the year 2051 reflects very close correlation to the projected population of 2051 by Geometric Increase Method i.e., the percentage of increase is almost the same as $80 \%$. This Land use Land cover changes findings strengthens the validity of the projected population. This study shows that the population may also be forecast 
by Land use Land cover analysis. The percentage increase of residential area and population growth since 1971 is given in the Table 2 .

Table 2. Percentage increase of population and residential area

\begin{tabular}{ccccc}
\hline Year & Population & $\begin{array}{c}\% \\
\text { increase }\end{array}$ & $\begin{array}{c}\text { Residential } \\
\text { area }\end{array}$ & $\begin{array}{c}\% \\
\text { increase }\end{array}$ \\
\hline 1971 & 241013 & - & & \\
\hline 1973 & & & 3.91 & \\
\hline 1981 & 291104 & 20.78 & & \\
\hline 1991 & 321454 & 10.43 & & \\
\hline 1992 & & & 7.53 & 92.58 \\
\hline 2001 & 411831 & 28.12 & & \\
\hline 2011 & 477838 & 16.03 & & \\
\hline 2012 & & & 9.65 & 28.15 \\
\hline $\begin{array}{c}2051 \\
\text { Expected }\end{array}$ & 905101 & & 17.4 & 80.31 \\
\hline
\end{tabular}

Table 3. Landuse landcover pattern of Tirunelveli LPA

\begin{tabular}{ccccc}
\hline Description & $\mathbf{1 9 7 3}$ & $\mathbf{1 9 9 2}$ & $\mathbf{2 0 1 2}$ & $\mathbf{2 0 5 1}$ \\
\hline Agricultural & $54.8 \%$ & $50.73 \%$ & $50.26 \%$ & $44.23 \%$ \\
\hline Dense scrub & $27.9 \%$ & $27.5 \%$ & $25.15 \%$ & $18.24 \%$ \\
\hline Village area & $2.19 \%$ & $2.61 \%$ & $2.63 \%$ & $3.28 \%$ \\
\hline Residential area & $3.91 \%$ & $7.53 \%$ & $9.65 \%$ & $17.4 \%$ \\
\hline River area & $0.68 \%$ & $0.68 \%$ & $0.68 \%$ & $0.68 \%$ \\
\hline Tank area & $8.43 \%$ & $8.22 \%$ & $8.13 \%$ & $7.56 \%$ \\
\hline Mining area & $0.87 \%$ & $1.69 \%$ & $2.48 \%$ & $5.67 \%$ \\
\hline Reserved forest & $0.99 \%$ & $0.99 \%$ & $0.99 \%$ & $0.99 \%$ \\
\hline
\end{tabular}

The Land use land cover predicted for the year 2051 from the available data of 1973, 1992 and 2012 shows that the percentage of agricultural area decreases to $44.23 \%$, dense scrub area decreases to $18.24 \%$, village area in the peri urban area decreases to $3.28 \%$, the residential area increases to $17.4 \%$, the river area to $0.68 \%$, the area of tank to $7.56 \%$, mining area increases to $5.67 \%$, and the total area of reserved forest to $0.99 \%$. This forecast of Landuse Landcover is shown in the Figure 4.

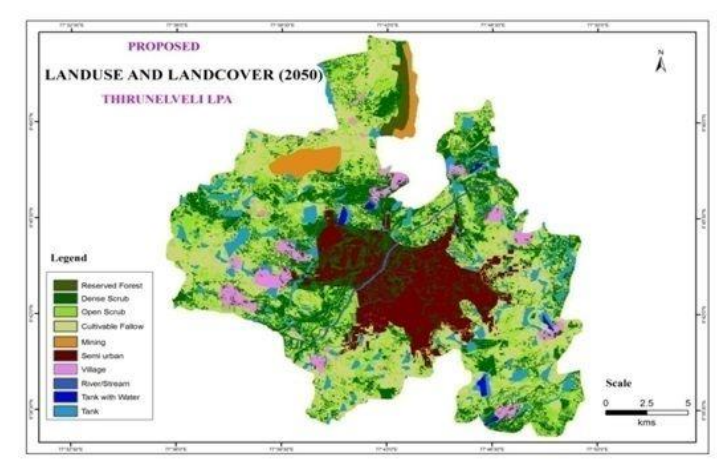

Figure 4. Landuse and Landcover of Tirunelveli LPA (2050)

Table 3 shows that the variation in usage of different LULC areas in Tirunelveli local planning area for the year 1973,
1992 and 2012 and are obtained from remote sensing images. The forecast of LULC for the year 2051 is also shown in Table 3 and is obtained from the rate of changes of land use pattern since 1973.

The land use land cover pattern shows that the city residential area grows haphazardly and at an abnormal rate. The village residential area also grows, but at a lesser rate compared to the city residential area. There are no change in reserved forest area and river area because of legislation and continuous monitoring by administrative authorities. The dense scrub area is reduced drastically by around 5\% since 1992. The tank area is also reduced to a lesser extent. The mining area is increased drastically by $30 \%$ since 1992.

\section{Rainfall and runoff analysis}

\subsection{Descriptive statistics}

The descriptive statistics of monthly rainfall is done from the year 1971 to 2011 which is shown in Table 4. The average annual rainfall of Tirunelveli city is $608 \mathrm{~mm}$ as obtained from the Palayankottai weather station. The standard deviation of annual rainfall is $260 \mathrm{~mm}$ which is $42 \%$ of the average annual rainfall. The maxium annual rainfall is $1461 \mathrm{~mm}$ which is $240 \%$ higher than the average annual rainfall. The minimum rainfall is $239 \mathrm{~mm}$ and is $39 \%$ lower than the average annual rainfall. The month of September, October, November, and December contributes to the surplus in average annual rainfall.

The annual rainfall data for the year 1971 to 2011 is shown in Figure 5 and the average monthly rainfall from the year 1971 to 2011 is shown in the form of pie chart in Figure 6 . This pie chart shows that the city receives most of the average annual rainfall during September to December. The rainfall is predominant during October to December as shown in Figure 7. The Skewness and Kurtosis coefficient is less during September to November which shows that the rainfall deviation from the normal monthly rainfall is minimum. The range of deviation for these months with observed and expected probability is less than 0.075 as inferred from P-P i.e. probability probability difference plot of September month as shown in the Figure 8.

The correlation matrix as given in the Table 5 is an proximity matrix and the correlation is insignificant. The significant correlation occurs between the month of Jan and September which is 0.436 and between November and May which is 0.543 . The P-P plot is studied for the month of September to December, since these four month provides maximum annual rainfall of a year. The P-P plot of these months shows increase in trend line where as the P-P plot of annual average rainfall shows flat trend line and slightly dipping towards the end. 
Table 4. Descriptive statistics of rainfall in Tirunelveli city

\begin{tabular}{|c|c|c|c|c|c|c|c|c|c|c|c|c|}
\hline \multicolumn{13}{|c|}{ Descriptive Statistics of Rainfall from the year 1971 to 2011} \\
\hline \multirow[b]{2}{*}{ Month } & \multirow{2}{*}{$\begin{array}{c}\mathbf{N} \\
\text { Statistic }\end{array}$} & \multirow{2}{*}{$\begin{array}{c}\text { Range } \\
\text { Statistic }\end{array}$} & \multirow{2}{*}{$\begin{array}{c}\text { Minimum } \\
\text { Statistic }\end{array}$} & \multirow{2}{*}{$\begin{array}{c}\text { Maximum } \\
\text { Statistic }\end{array}$} & \multirow{2}{*}{$\begin{array}{c}\text { Sum } \\
\text { Statistic }\end{array}$} & \multicolumn{2}{|c|}{ Mean } & \multirow{2}{*}{$\begin{array}{c}\text { Std. Deviation } \\
\text { Statistic }\end{array}$} & \multirow{2}{*}{$\begin{array}{l}\text { Variance } \\
\text { Statistic }\end{array}$} & \multirow{2}{*}{$\begin{array}{c}\text { Skewness } \\
\text { Statistic }\end{array}$} & \multirow[b]{2}{*}{$\begin{array}{l}\text { Std. } \\
\text { Error }\end{array}$} & \multirow{2}{*}{$\begin{array}{l}\text { Kurtosis } \\
\text { Statistic }\end{array}$} \\
\hline & & & & & & Statistic & $\begin{array}{l}\text { Std. } \\
\text { Error }\end{array}$ & & & & & \\
\hline Jan & 42 & 221 & 0 & 221.00 & 845.00 & 20.12 & 6.39 & 41.41 & 1714.95 & 3.52 & 0.37 & 14.06 \\
\hline Feb & 42 & 194 & 0 & 194.00 & 914.90 & 21.78 & 6.75 & 43.73 & 1912.28 & 3.10 & 0.37 & 9.67 \\
\hline Mar & 42 & 190.7 & 0 & 190.70 & 1281.10 & 30.50 & 7.07 & 45.79 & 2096.84 & 1.90 & 0.37 & 3.25 \\
\hline Apr & 42 & 175.2 & 0 & 175.20 & 1778.50 & 42.35 & 7.25 & 47.02 & 2210.55 & 1.48 & 0.37 & 1.56 \\
\hline May & 42 & 291 & 0 & 291.00 & 1780.30 & 42.39 & 9.16 & 59.38 & 3525.83 & 2.98 & 0.37 & 9.77 \\
\hline Jun & 42 & 115 & 0 & 115.00 & 356.70 & 8.49 & 3.20 & 20.72 & 429.35 & 3.95 & 0.37 & 17.59 \\
\hline Jul & 41 & 59 & 0 & 59.00 & 294.40 & 7.18 & 2.13 & 13.66 & 186.49 & 2.61 & 0.37 & 6.33 \\
\hline Aug & 42 & 89 & 0 & 89.00 & 682.70 & 16.25 & 3.61 & 23.39 & 547.07 & 1.69 & 0.37 & 2.17 \\
\hline Sep & 41 & 106 & 0 & 106.00 & 1564.30 & 38.15 & 4.85 & 31.06 & 964.48 & 0.66 & 0.37 & -0.52 \\
\hline Oct & 41 & 338.8 & 4 & 342.80 & 5375.60 & 131.11 & 13.51 & 86.49 & 7480.39 & 0.92 & 0.37 & 0.39 \\
\hline Nov & 41 & 431.8 & 24 & 456.00 & 7385.70 & 180.14 & 16.24 & 103.97 & 10810.70 & 0.90 & 0.37 & 0.27 \\
\hline Dec & 41 & 320.8 & 0 & 320.80 & 3282.60 & 80.06 & 11.57 & 74.09 & 5490.01 & 1.57 & 0.37 & 2.61 \\
\hline AAR & 42 & 1443.7 & 241 & 1461.70 & 25541.90 & 608.14 & 40.22 & 260.63 & 67927.38 & 0.99 & 0.37 & 3.07 \\
\hline
\end{tabular}

Table 5. Proximity matrix - Absolute rainfall correlation between months

\begin{tabular}{|c|c|c|c|c|c|c|c|c|c|c|c|c|}
\hline \multicolumn{13}{|c|}{ Proximity Matrix } \\
\hline \multicolumn{13}{|c|}{ Absolute Correlation between Vectors of Values } \\
\hline & Jan & Feb & Mar & Apr & May & Jun & Jul & Aug & Sep & Oct & Nov & Dec \\
\hline Jan & 1.000 & & & & & & & & & & & \\
\hline Feb & .247 & 1.000 & & & & & & & & & & \\
\hline Mar & .122 & .254 & 1.000 & & & & & & & & & \\
\hline Apr & .071 & .308 & .237 & 1.000 & & & & & & & & \\
\hline May & .119 & .299 & .129 & .233 & 1.000 & & & & & & & \\
\hline Jun & .009 & .143 & .105 & .051 & .116 & 1.000 & & & & & & \\
\hline Jul & .122 & .150 & .073 & .005 & .005 & .114 & 1.000 & & & & & \\
\hline Aug & .200 & .088 & .123 & .003 & .255 & .004 & .027 & 1.000 & & & & \\
\hline Sep & .436 & .331 & .003 & .115 & .397 & .075 & .083 & .009 & 1.000 & & & \\
\hline Oct & .107 & .077 & .076 & .047 & .097 & .077 & .215 & .087 & .125 & 1.000 & & \\
\hline Nov & .031 & .168 & .072 & .258 & .543 & .165 & .092 & .159 & .356 & .154 & 1.000 & \\
\hline Dec & .119 & .213 & .310 & .161 & .303 & .017 & .262 & .051 & .077 & .012 & .119 & 1.000 \\
\hline
\end{tabular}

This is an absolute similarity matrix 
Table 6. Regression correlation between monthly rainfall and annual rainfall

\begin{tabular}{|c|c|c|c|c|c|c|}
\hline \multicolumn{7}{|c|}{ Coefficients $^{\mathrm{a}}$} \\
\hline \multirow{2}{*}{ Model } & \multicolumn{3}{|c|}{ Unstandardized Coefficients } & \multirow{2}{*}{$\begin{array}{c}\begin{array}{c}\text { Standardized } \\
\text { Coefficients }\end{array} \\
\text { Beta }\end{array}$} & \multirow[t]{2}{*}{$\mathbf{T}$} & \multirow[t]{2}{*}{ Sig. } \\
\hline & & B & Std. Error & & & \\
\hline \multirow[t]{13}{*}{1} & (Constant) & -.006 & .009 & & -.655 & .518 \\
\hline & Jan & 1.000 & .000 & .169 & 1.284E4 & .000 \\
\hline & Feb & 1.000 & .000 & .179 & $1.353 \mathrm{E} 4$ & .000 \\
\hline & Mar & 1.000 & .000 & .187 & 1.527E4 & .000 \\
\hline & Apr & 1.000 & .000 & .176 & 1.479E4 & .000 \\
\hline & May & 1.000 & .000 & .242 & $1.478 \mathrm{E} 4$ & .000 \\
\hline & Jun & 1.000 & .000 & .085 & 7.654E3 & .000 \\
\hline & Jul & 1.000 & .000 & .055 & $4.758 \mathrm{E} 3$ & .000 \\
\hline & Aug & 1.000 & .000 & .095 & $7.680 \mathrm{E} 3$ & .000 \\
\hline & Sep & 1.000 & .000 & .124 & $8.828 \mathrm{E} 3$ & .000 \\
\hline & Oct & 1.000 & .000 & .349 & 3.074E4 & .000 \\
\hline & Nov & 1.000 & .000 & .422 & $2.982 \mathrm{E} 4$ & .000 \\
\hline & Dec & 1.000 & .000 & .299 & $2.370 \mathrm{E} 4$ & .000 \\
\hline
\end{tabular}

Dependent Variable: $A R$

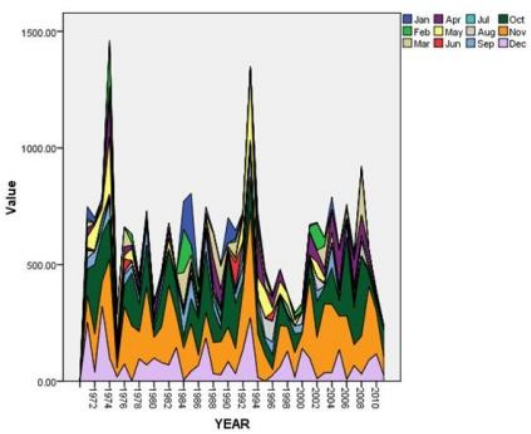

Figure 5. Average annual rainfall of Tirunelveli city

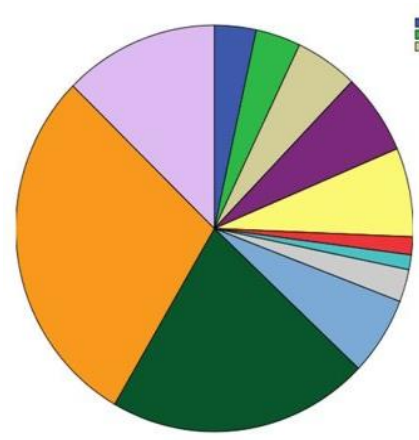

Figure 6. Average monthly rainfall of Tirunelveli city

The box plot is drawn for montly rainfall Vs year of rainfall which is shown in Figure 9. This plot shows the month of September, October and November have less deviation from the average, where as all other months shows more variation from the normal average. The year 1974 and 1993 annual rainfall are the highest and exceeds the average annual rainfall. The box plot shows these years is not within the range of Average Rainfall (AR) and the deviation is abnormal. The box plot shows that the north east monsoon is highly reliable and planning is effective during these months for fresh water resources management.

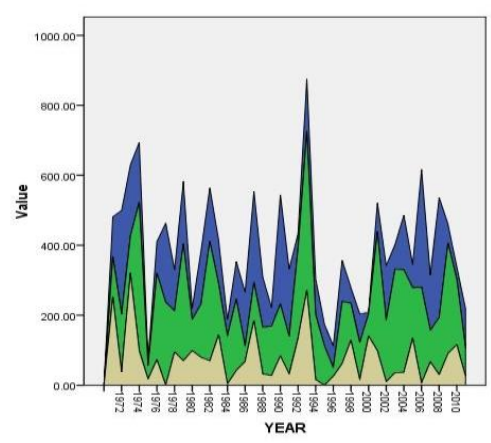

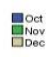

Figure 7. Average monthly rainfall for October, November and December

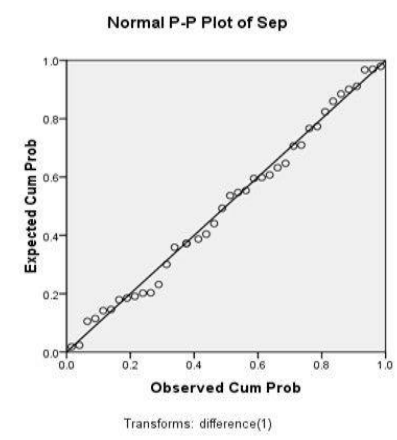

Figure 8. P-P plot for the month of September 


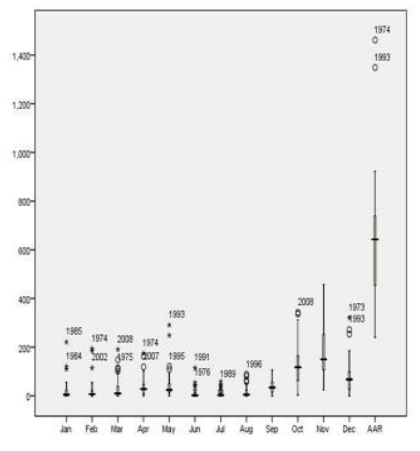

Figure 9. Box plot for monthly rainfall Vs year of rainfall

\subsection{Regression analysis}

A wholistic approach is done to findout the individual monthly contribution to the Annual Rainfall (AR) by linear regression as shown in Table 6 . This annual rainfall in turn influences Annual average rainfall (AAR) over a period of years. The linear regression correlation is analysed on the rainfall data for all the month in a year against $A R$. The monthly rainfall is taken as independent variables and annual rainfall as dependent variable. The standardized beta coefficients are higher for the month of November followed by October and December which are as 0.422 , 0.349 and 0.299 respectively. This regression shows that the contribution of rainfall in November is most influencing the AR followed by October, December. This correlation shows that these months provide the most of the rainfall in a year. This also shows that the north east monsoon is highly reliable too for planning fresh water resources management.

\subsection{Three years moving average rainfall analysis}

Three years moving average shows that the AAR moves above $800 \mathrm{~mm}$ to $950 \mathrm{~mm}$ since 2005 which is shown in Figure 10. This average has wide variation from 1970 oscillating from around $400 \mathrm{~mm}$ to $660 \mathrm{~mm}$ till 1984 . Thereafter it oscillates from $420 \mathrm{~mm}$ to $820 \mathrm{~mm}$ till 2000 . A shot duration of three years moving average has been analysed for planning to obtain a immediate improvement on fresh water resources management.

\subsection{Water demand analysis}

The Table 7 shows that a minimum of $17.33 \mathrm{M} \mathrm{m}^{3}$ of water is required to meet the demands of the Tirunelveli city at 100 lpcd (litres per capita per day), but only 14.71 $\mathrm{M} \mathrm{m}^{3}$ is supplied from various water works. This implies that around $15.1 \%$ of the present population does not have access to water supply or relies on other sources of water possibly groundwater. The gap widens and more than $55.5 \%$ of the future population as obtained from forecast, may not have access to water in the year 2050 at 100 lpcd, if proper effective management of fresh water resources is done.
4.5. Groundwater recharge potential and Surface runoff analysis

The groundwater analysis is done using both the methods of a) Fluctuation method and b) Rise and Fall method. This method uses average increase and decrease in groundwater piezometric level. The surface runoff analysis is done using SCS curve method to obtain the quantum of runoff generated from rainfall. These estimated surface runoff and groundwater may be effectively planned for utilizing the water in various purposes such as to meet the demands of the present and anticipated future population, and for agricultural purposes.

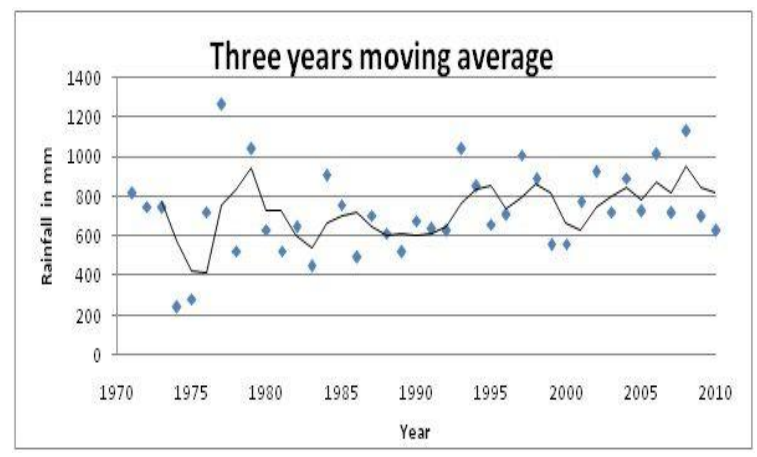

Figure 10. Three years moving average of annual rainfall

Table 7. Present and future demand of water supply in Tirunelveli

\begin{tabular}{|c|c|c|c|}
\hline \multirow[t]{2}{*}{ SI. No. } & \multirow[t]{2}{*}{ Description } & \multicolumn{2}{|c|}{$\begin{array}{c}\text { Annual requirements } \\
\left(\mathrm{M} \mathrm{m}^{3}\right) \text { at }\end{array}$} \\
\hline & & 100 Ipcd & 135 Ipcd \\
\hline 1 & $\begin{array}{c}\text { Requirement as per } \\
2011 \text { population of } \\
4,74,838\end{array}$ & 17.33 & 23.39 \\
\hline 2 & $\begin{array}{l}\text { Requirement for the } \\
\text { ultimate } 2051 \\
\text { population of } 9,05,101\end{array}$ & 33.03 & 44.59 \\
\hline 3 & $\begin{array}{c}\text { Present availability } \\
\text { (eleven water supply } \\
\text { head works) }\end{array}$ & 14.71 & 14.71 \\
\hline 4 & $\begin{array}{l}\text { Present deficit as on } \\
2011\end{array}$ & $\begin{array}{c}2.62 \\
(15.1 \%) \\
\end{array}$ & $\begin{array}{c}8.68 \\
(59.0 \%) \\
\end{array}$ \\
\hline 5 & $\begin{array}{l}\text { Anticipated deficit in } \\
2051\end{array}$ & $\begin{array}{c}18.32 \\
(105.7 \%)\end{array}$ & $\begin{array}{c}29.88 \\
(203.1 \%)\end{array}$ \\
\hline
\end{tabular}

\subsubsection{Groundwater recharge potential}

Ground water estimation is done using the monthly ground water level data collected from the State Ground water resource data centre and estimated based on the following two methods. The groundwater level collection points of State ground water resources is shown in Figure 11. The ground water level points used for the study are shown in figure given below with the ID numbers. The groundwater level data is not presented here. The groundwater potential is estimated for the Tirunelveli city of corporation area 108.65 
- Fluctuation method

- $\quad$ Rise and Fall method

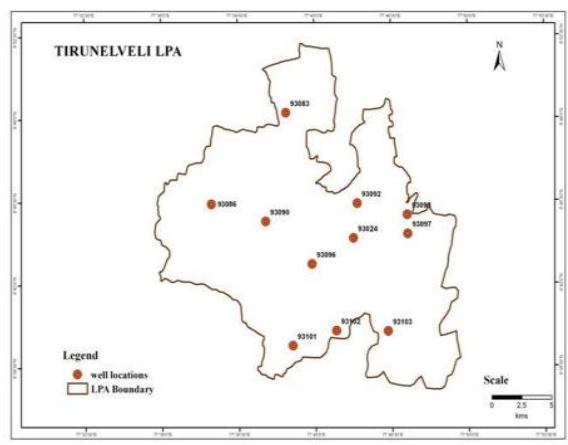

Figure 11. Groundwater level data points of Tirunelveli LPA

\subsubsection{Groundwater potential estimation}

\section{Fluctuation method}

The corporation area of 108 sq.km., and only a specific yield of $3 \%$ is considered. The average change in water level in the area is $0.673 \mathrm{~m}$. The average ground water potential is calculated as follows and is $2.18 \mathrm{Mm}^{3}$ of water in fluctuation method.

Average groundwater potential(GWP) = Area $\mathrm{x}$ Specific Yield $\times$ Average change in water level $=$ 108 sq. $\mathrm{km} \times 3 \% \times 0.673 \mathrm{~m}=2.18 \mathrm{Mm}^{3}$

\section{Rise and fall method}

The ground water potential is also estimated using maximum rise and fall method from groundwater level. The difference in average maximum rise and maximum fall for the past five years is $2.1925 \mathrm{~m}$ and ground water potential is $7.1037 \mathrm{Mm}^{3}$ of water.

Average groundwater potential (GWP) = (Avg.Maximum rise - Avg.Maximum fall) $x$ Area x Specific yield $=2.1925 \mathrm{~m} \times 108 \mathrm{sq} . \mathrm{km} \times 3 \%$ (specific yield) $=7.1037 \mathrm{Mm}^{3}$

The average groundwater potential with $3 \%$ specific yield shows a minimum of $2.18 \mathrm{Mm}^{3}$ and a maximum of 7.1 $\mathrm{Mm}^{3}$

\subsection{Surface runoff analysis}

The north east monsoon provides a maximum rainfall in a year as established from regression analysis and is considered for surface runoff analysis. The surface runoff is being estimated by using the United States Department of Agriculture Soil Conservation Service Curve Number technique as shown in Table 8. By this method the generated surface runoff is quantified as $41.32 \mathrm{M} \mathrm{m}^{3}$ for a $75 \%$ dependable rainfall of $25 \mathrm{~mm}$ at any instance of a year and the runoff estimated is $20 \mathrm{Mm}^{3} /$ year. The total capacity of the tanks as calculated from the data of the Public works department of Tamil Nadu are $8.63 \mathrm{Mm}^{3}$ for large capacity tanks and $3.15 \mathrm{Mm} 3$ for small capacity tanks with total surface water retaining capacity of 11.78 $\mathrm{Mm}^{3}$. The water shed area and the tanks are shown in Figure 12. The recharge ground potential is only around $2.18 \mathrm{Mm}^{3}$ to $7.1 \mathrm{Mm}^{3}$ for the local planning area as found out from Fluctuation and Rise \& Fall method of aquifers. This shows that around 1 to $6 \mathrm{Mm}^{3}$ of rain water drains into the river annually from Tirunelveli LPA for any one intensified rainfall.

Table 8. Surface runoff estimation by SCS curve method

\begin{tabular}{|c|c|c|c|c|c|c|c|}
\hline & $\begin{array}{l}\text { Area in } \\
\text { Hectare }\end{array}$ & $\begin{array}{l}\text { Curve } \\
\text { number } \\
\text { (CN) }\end{array}$ & $\begin{array}{c}S=(1000 / \\
C N-10)\end{array}$ & $\begin{array}{l}P \text { (Total } \\
\text { rainfall) } \\
\text { in inch }\end{array}$ & $\begin{array}{c}Q=\left\{(P-0.2 S)^{2} /\right. \\
(P+0.8 S)\} \text { in } \\
\text { inch }\end{array}$ & Qin $\mathbf{M}^{3}$ & $\begin{array}{l}Q \text { in } \\
\mathrm{Mm}^{3}\end{array}$ \\
\hline Residential & 1202.18 & 92 & 12.195 & 25.122 & 14.75 & 4504540.32 & 4.50 \\
\hline Commercial & 91.83 & 95 & 11.765 & 25.122 & 15.01 & 350158.39 & 0.35 \\
\hline Industrial & 216.02 & 93 & 12.048 & 25.122 & 14.84 & 814264.63 & 0.81 \\
\hline Educational & 238.74 & 95 & 11.765 & 25.122 & 15.01 & 910343.17 & 0.91 \\
\hline $\begin{array}{c}\text { Public \& Semi } \\
\text { Public }\end{array}$ & 290.98 & 92 & 12.195 & 25.122 & 14.75 & 1090295.25 & 1.09 \\
\hline Dry & 407.80 & 89 & 12.658 & 25.122 & 14.48 & 1499634.33 & 1.50 \\
\hline Wet & 4027.03 & 91 & 12.346 & 25.122 & 14.66 & 14997361.40 & 15.00 \\
\hline Transportation & 661.22 & 98 & 11.364 & 25.122 & 15.26 & 2562916.50 & 2.56 \\
\hline Hillocks & 285.60 & 98 & 11.364 & 25.122 & 15.26 & 1106997.60 & 1.11 \\
\hline \multirow[t]{2}{*}{ Water Bodies } & 3443.60 & 100 & 11.111 & 25.122 & 15.42 & 13486242.64 & 13.49 \\
\hline & 10865.00 & & & & & & 41.32 \\
\hline
\end{tabular}

Source: Field survey conducted by Regional Office of local planning authority - 2005 


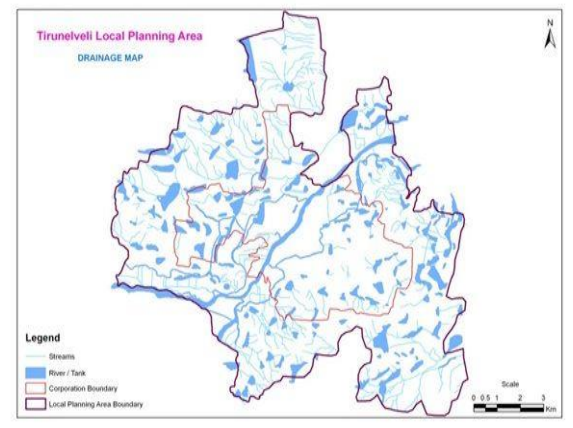

Figure 12. Watershed area and Tanks of Tirunelveli area

\section{Standardized Precipitation Index}

Standardized precipitation index (SPI), developed in 1993 by Thomson b. Macke (Mckee et al., 1993) to measure the precipitation deficit for multiple time scale. This SPI is the ratio of difference in precipitation and mean precipitation to the standard deviation,

$\mathrm{SPI}=(\mathrm{X}-\mathrm{Xm}) / \sigma$

Where $\mathrm{X}$ and $\mathrm{Xm}$ is precipitation and mean precipitation and $\sigma$ is standardized deviation (Mundetia and Sharma, 2015). The long-term record is analyzed and fitted to a probability distribution. This probability distribution is then transformed into a normal distribution so that the mean SPI becomes zero for the location and desired period.(Katsabani and Mavrakis, 2011).

The SPI chart for Tirunelveli city is shown in Figure 13 and is used to find out the monthly normal, wet, and dry conditions (Nasrin Salehnia et al., 2017). This figure shows that the extreme wet condition (value >2) has not occurred after 1992. The SPI varies from -0.5 to -1.6 from the year 1995 to 2002 which indicates near normal to severly dry condition. The SPI is nearly normal (-0.99 to 0.99) since 2000 except in 2007. This shows that the moderately wet condition do occur only in 2007. The above variation in SPI clearly indicates the change in climate pattern. SPI is also drawn for monthly variations from 1971 to 2011. These figures are drawn for every decade for better clarity and readability. SPI is also categorized for monthly variations too form Figure 14.

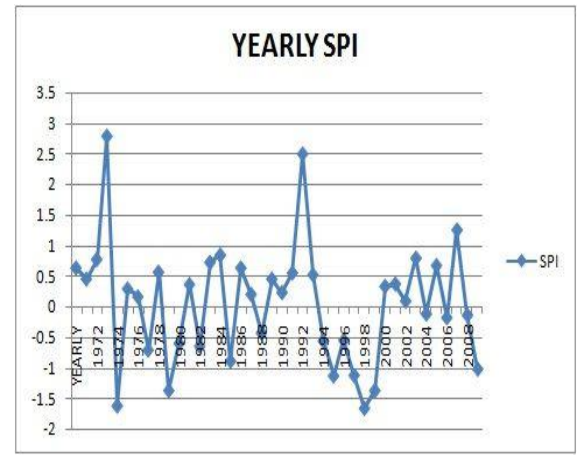

Figure 13. SPI index for yearly rainfall

\subsection{Drought Index (DI)}

The drought index(DI) or effective drought index(EDI) is calculated as shown in the equation below:

$E P=\sum_{n=1}^{i}\left\{\frac{\left[\sum_{m=1}^{j} P m\right]}{n}\right\}$

$D E P=E P-M E P$

$\mathrm{DI}$ or $\mathrm{EDI}=\mathrm{DEP} / \mathrm{SD}(\mathrm{DEP})$

Where EP represent the valid accumulations of precipitation and $\mathrm{Pm}$ represents the precipitation level for a day, " $m$ " days prior to a specific date. "i" begins from 365. Therefore, EP becomes the valid accumulation of precipitation for 365 days from a particular date. DEP represents the deviation of EP from MEP (30-year average EP for the calendar date). When DEP is negative for two consecutive days, "i" becomes $366(=365+2-1)$ and the calculation begins once again. Therefore, the drying effect on the soil from a drought that occurred several years ago is reflected in the EDI (Byun and Wilhite (1999).

The drought index for Tirunelveli city is shown in the Figure 15. This chart shows the drought condition of a year as no drought $(>5)$, weak drought (4), moderate drought (3), severe drought (2) and extreme drought (1) (Nasrin Salehnia et al., 2017). This figures shows that no drought to extreme drought condition prevails alternatively from the year 1971 and till 2000. This figure also shows that no or weak drought condition occurs since 2001 except in the year 2010 which is in severe drought condition. These indication clearly show that there is a change in climatic pattern. DI is also drawn for monthly variations from 1971 to 2011. DI is also categorized for monthly variations too form Figure 16.
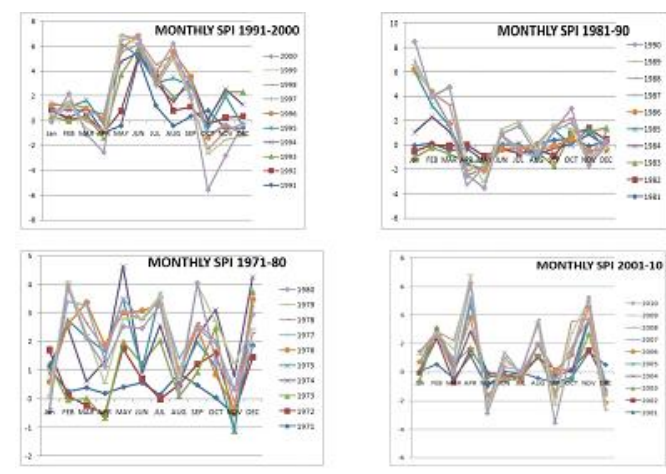

Figure 14. SPI index for monthly rainfall 


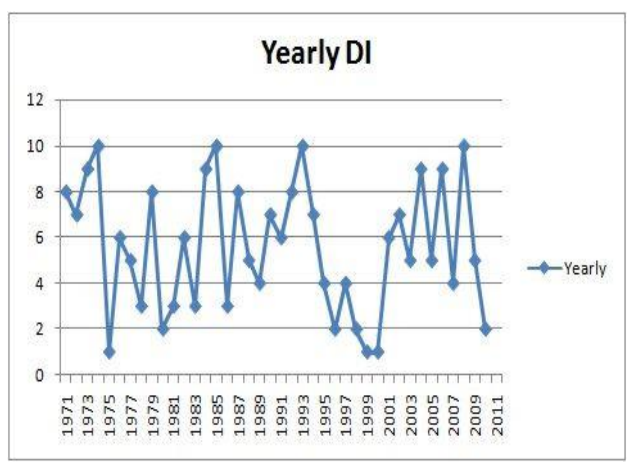

Figure 15. DI for yearly rainfall

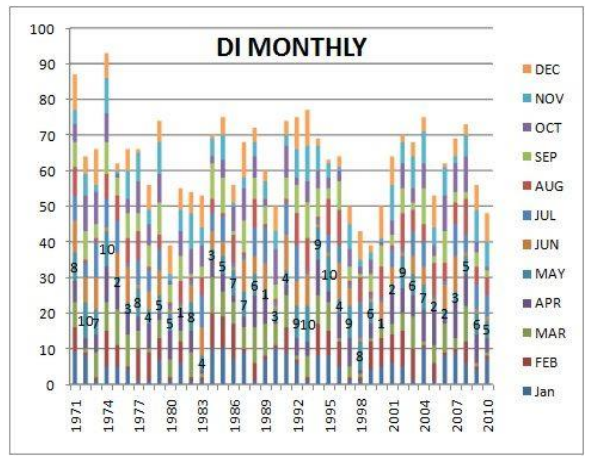

Figure 16. DI for monthly rainfall

\section{Conclusions}

The rainfall pattern in Tirunelveli district is errotic or intensified within a shorter duration. This intensified rainfall creates more runoff and creates fresh water scarcity in most of the days in a year. The AR during the year 1974 and 1993 is the highest. The AAR versus year of rainfall plot shows slight dip in the year 2011 . The average annual rainfall of Tirunelveli city is $608 \mathrm{~mm}$. The standard deviation of average annual rainfall is $260 \mathrm{~mm}$ which is $42 \%$ of the average annual rainfall. The maximum annual rainfall is $240 \%$ higher than the average annual rainfall. The minimum rainfall is $39 \%$ lower than the average annual rainfall. The month of September, October, November, and December contributes most of the annual rainfall in a year. The deviation in any one year in average monthly rainfall is least during the month of September, October and November. These months bring rainfall with the onset of north east monsoon. The plot of these months versus AR shows that the increase in monthly rainfall of these months increases AR. The standardized beta coefficient of regression analysis shows the rainfall in November is most influencing in AR followed by October and December. The deviation from normal average monthly rainfall is less in the month of the September, October, November and December. The increase in annual rainfall increases rainfall in the month of September, October, November and December. Rainfall analysis data of this city reveals that the month of November, October, December and September provides around 60 to $65 \%$ of the annual rainfall (AR). The increase or decrease in the AR of a year reflects predominantly in these months. P-P (observed and predicted probability) plot shows that the rainfall is consistent in these months. The Skewness and Kurtosis coefficient is less during the month of September to November which shows that the rainfall deviation from the normal monthly rainfall is minimum. The total surface runoff generated from the city is $41 \mathrm{Mm}^{3}$ per year. The average north east monsoon alone provides a runoff water of $20 \mathrm{Mm}^{3}$ per year. The existing tank capacity in this region is about 11.83 $\mathrm{Mm}^{3}$ per year and nearly $8.17 \mathrm{Mm}^{3}$ per year is drained off from the areas during this season. The recharge ground potential is around $2.18 \mathrm{Mm}^{3}$ to $7.1 \mathrm{Mm}^{3}$ and nearly $40 \%$ of runoff is drained to the Tamirabarani river. The land use land cover pattern shows that the city residential area grows haphazardly and at an abnormal rate. The village residential area also grows but at a lesser rate compared to the city residential area. There is no change in reserved forest area, river area because of legislation and continuous monitoring by the administrative authorities. The dense scrub area is reduced to $25.15 \%$ in the year 2012 from $27.5 \%$ in the year 1992. The tank area is reduced to the least extent. The mining area is increased drastically from $1.69 \%$ in the year 1992 to $2.48 \%$ in the year 2012. The increase in residential area is directly proportional to the growth of the population and well correlated with the present trend of geometric increase of the population. The Land use Land cover pattern shows Linear ribbon growth development or the development is horizontal in Tirunelveli LPA. The Land use pattern reflects the trend of the habitats and thereby the forecast of the population growth is easily obtained from LULC analysis. The LULC analysis along with the knowledge of residential area development is useful in forecasting of the population with ease, as and when required, which saves time, man power, effort and money to be spent on census with the help of IT (Information Technology). This established relationship may be helpful for the policy makers to plan and regulate the development of the city. The city needs sustainable planning and management to protect the water bodies thereby fresh water resources and the loss of agricultural land. The study shows that the Remote Sensing and Geographical Information Systems (RS-GIS) techniques may be used effectively to forecast population, to evaluate the loss of agricultural land due to urban expansion, and also to findout the exploitation of other environmental natural resources.

\section{Acknowledgement}

We thank our Management and the Principal of Thiagarajar College of Engineering, Madurai, for encouraging in research activities and also providing us with all the resource facilities for deepening our knowledge through library, e-resources, journals, software and internet required for conducting successfully this research work. We thank the Department of United States Geological Survey for distributing the RS images which are very useful for this study. We thank the State Groundwater Resource Department of Public Works Department, Tamil Nadu Water supply and Drainage Board(TWAD), Tamil Nadu Agriculture Weather Network, and Tirunelveli Municipal Corporation for providing the relevant data to complete this work. We also thank AgriMetSoft for distributing free software MDM which is used in this study to find drought and precipitation index. We thank all 
the people for their valuable suggestion and comments during the course of the work. We thank all the authors referred herein and to the authors contributing similar nature of the work to the world for effective management of fresh water resources. Finally, we thank all the peer reviewers for their fruitful comments to enhance the quality of this paper.

\section{References}

Aggarwal S.C. and Kumar S. (2011), Industrial Water Demand in India Challenges and Implications for Water Pricing, India infrastructure report.

Akosa G., Franceys R., Barker P. and Weyman-Jones T. (1995) Efficiency of water-supply and sanitation projects in Ghana, American Society of Civil Engineers, 1995(1), 56-65.

Ashofteh P.-S., Bozorg-Haddad O., Mariño M.A. (2014), Discussion of "estimating the effects of climatic variability and human activities on streamflow in the Hutuo River Basin, China", Journal of Hydrology Engineering, 19(4), 836-836.

Awuah E., Nyarko_ K.B. and Owusu P.A. (2009), Water and sanitation in Ghana, Journal of Desalination, 248 (2009) 460467.

Batta B. (2010), Analysis of URBAN Growth and Sprawl from Remote Sensing Data. Springer-Verlag Berlin Heidelberg.

Batty M. (1999), Geopatial analysis and modelling of urban structure and dynamics, The Geojournal.

Chandra S. (1979), Estimation and measurement of recharge to groundwater from rainfall, irrigation and influent seepage, Proceedings, International Seminar on Development and Management of Groundwater Resources, 5-20 November 1979, School of Hydrology, University of Roorkee, Roorkee, pp. III-9 to III-17.

Chandra S. (1983), Hydrological investigations in ground water resources evaluation, Proceedings (Volume III), Seminar on Assessment, Development and Management of Ground Water Resources, New Delhi, 29-30 April 1983, pp.2-19 to 234.

Chandra S. and Saksena R.S. (1975), Water balance study for estimation of ground water resources, Journal of Irrigation and Power, India, 443-449.

Chandra S., Saksena R.S. and Kashyap D. (1979), Water balance study for estimation of groundwater recharge, Proceedings, International Seminar on Development and Management of Groundwater Resources, 5-20 November 1979, School of Hydrology, University of Roorkee, Roorkee, pp.III-22 to III-24.

Chandrasekar N., Sivasubramanian P and Soundranayagam J.P. (2010), Ecological consequences of rapid urban expansion: Tirunelveli, India, African Journal of Basic \& Applied Sciences, 2(5-6), 167-176, 2010.

Chau K.W., Wu and C.L. (2010), A hybrid model coupled with singular spectrum analysis for daily rainfall prediction, Journal of Hydrology infection, 12(4), 458-473.

Coombes P.J., Boubli D. and Argue J. (2003), Integrated Water Cycle Management at the Heritage Mews Development in Western Sydney. Presented at the 28th International Hydrology and Water resources Symposium, The Institution of Engineers, Australia, Wollongong, NSW, Australia, 10-14 November 2003.

Daniel Y., Hernandez P., Burke T., Stanek P., Stidham K., Mackay R. and Spencer E. (2005), Integrated Urban Water Management in Dunedin, Florida. United States Global
Change Research Program. (n.d.). Coasts. Retrieved 12 20, 2010.

"Ground Water Estimation Methodology", Report of the Ground Water Estimation Committee, Ministry of Irrigation, Government of India, New Delhi, March 1984.

HigaEdaa L.E. and Chen W. (2010), Integrated water resources management in Peru, Journal of Environmental Science, 2, 340-348.

IPCC-TGCIA (1999), Guidelines on the use of scenario data for climate impact and adaptation assessment. Version 1. Prepared by Carter T.R., Hulme $M$. and Lal $M$. Intergovernmental Panel on Climate Change. Task Group on Scenarios for Climate Impact Assessment.

Karanth K.R. (1987), Ground Water Assessment, Development and Management, Tata McGraw-Hill Publishing Company Limited,New Delhi, pp. 576-657.

Lairenjam C., Hodam S., Bandyopadhyay A. and Bhadra A., Global NEST Journal, 19(4), 547-561.

Lévite H., Sally H. and Cour J. (2003), Testing water demand management scenarios in a water-stressed basin in South Africa: application of the WEAP model, Physics and Chemistry of the Earth, Parts $A / B / C, 28(20-27), 779-786$.

Maheepala S. and Blackmore J. (2008), Integrated urban water management for cities. In: Newton P.W. (ed.), Transition: Pathways Towards Sustainable Urban Development in Australia, Published by CSIRO Publishing, pp. 461-478.

Maheepala S., Blackmore J., Diaper C., Moglia M., Sharma A. and Kenway S. (2010), Manual for Adopting Integrated Urban Water Management for Planning, Water Research Foundation (Project 4008), 6666 West Quincy Avenue, Denver, CO 80235-3098.

Mubea K.W. (2012), Monitoring land-use change in Nakuru (Kenya) using multi-sensor satellite data, Advances in Remote Sensing, 1, 74-84.

Mundetia N. and Sharma D. (2015), Analysis of rainfall and drought in Rajasthan State, India, Global NEST Journal, 17(1), 12-21.

Mundia C.N. and Aniya M. (2005), Analysis of land use land cover changes and urban expansion of Nairobi City using remoote sensing, International Journal of Remote Sensing, 2831-2849.

Odhiambo J.O., Martinsson E., Soren S., Mboya P. and Onyango J. (2009), Integration water, energy and sanitation solution for stand-alone settlements, Journal of Desalination, 248, 570-577.

Pham H.M. and Yamaguch Y. (2011), Urban growth and change analysis using remote sensing and spatial metrics fom 1975 to 2003 for Hanoi, Vietnam, International Journal of Remote Sensing, 32(7), 1901-1915.

Rai S.C. (2011), Water management for a megacity: National capital territory of Delhi, Water Resource Management, 25, 2267-2278.

Raskin P., Hansen E., Stavisky D. and Zhu Z. (1992), Simulation of water supply and demand in the Aral sea region, Water International, 17(2), 55-67

Ravindra K.V. (2008), Application of remote sensing and GIS technique for efficient urban planning in India.

Salehnia N., Alizadeh A., Sanaeinejad H., Bannayan M., Zarrin A. and Hoogenboom G. (2017), Estimation of meteorological drought indices based on AgMERRA precipitation data and station-observed precipitation data, Journal of Arid Land, 9(6), 797-809. 
Sarkar A. (2015), Impact of climate change poses a high threat to the water resources of the globe, Global NEST Journal, 17(2), 323-333.

Sokolov A.A. and Chapman T.G. (1974), Methods for Water Balance Computations, The UNESCO Press, Paris.

SWITCH Visioning Briefing Note: Developments in Integrated Urban Water Management (IUWM). SWITCH. (n.d.). News. Retrieved 12 15, 2010, from SWITCH Managing Water for the City of the Future: http://www.switchurbanwater.eu/news.php

Tamil nadu water supply drainage board-Tirunelveli corporationunderground sewerage scheme manual 2006.

Tamilnadu Urban Infrastructure Financial Services Limited-Final Report - Tirunelveli Municipal Corporation- FEBRUARY 2007.

Taormina R. and Chau K.-W. (2015), Data-driven input variable selection for rainfall-runoff modeling using binary-coded particle swarm optimization and extreme learning machines, Journal of Hydrology, 529(3), 1617-1632.

Tucci C.E.M. (2009), Integrated Urban Water Management in Jakarta, World Bank- Water Week. 